of pembrolizumab as first-line therapy for advanced non-small cell lung cancer", Lung Cancer, 124, pp. 248-254.

4. Huang $M$ et al (2019), "Cost-effectiveness of pembrolizumab versus chemotherapy as first-line treatment in PD-L1-positive advanced non-smallcell lung cancer in the USA", Immunotherapy, 11(17), pp. 1463-1479.

5. Huang M. et al (2017), "Cost Effectiveness of Pembrolizumab vs. Standard-of-Care Chemotherapy as First-Line Treatment for Metastatic NSCLC that Expresses High Levels of PD-L1 in the United States", Pharmacoeconomics, 35(8), pp. 831-844.

6. Insinga $\mathbf{R}$. P. et al (2018), "Cost-effectiveness of pembrolizumab in combination with chemotherapy in the 1st line treatment of nonsquamous NSCLC in the US", J Med Econ, 21(12), pp. 1191-1205.

7. Insinga R. P. et al (2019), "Cost-effectiveness of pembrolizumab in combination with chemotherapy versus chemotherapy and pembrolizumab monotherapy in the first-line treatment of squamous non-small-cell lung cancer in the US", Curr Med Res Opin, 35(7), pp. 1241-1256.
8. She L. et al (2019), "Cost-effectiveness analysis of pembrolizumab versus chemotherapy as firstline treatment in locally advanced or metastatic non-small cell lung cancer with PD-L1 tumor proportion score $1 \%$ or greater", Lung Cancer. 138 , pp. 88-94.

9. Wan N. et al (2020), "Cost-effectiveness analysis of pembrolizumab plus chemotherapy with PD-L1 test for the first-line treatment of NSCLC, Cancer Med, 9(5), pp. 1683-1693.

10.Wu B. et al (2020), "The effect of PD-L1 categories-directed pembrolizumab plus chemotherapy for newly diagnosed metastatic nonsmall-cell lung cancer: a cost-effectiveness analysis", Transl Lung Cancer Res, 9(5), pp. 1770-1784.

11.Zeng $X$. et al (2017), "Cost-effectiveness analysis of pembrolizumab plus chemotherapy for previously untreated metastatic nonsmall cell lung cancer in the USA", TheOncologist, 22, pp. 1392-1399.

12.Zhou K. et al (2019), "Cost-effectiveness analysis of pembrolizumab monotherapy and chemotherapy in the non-small-cell lung cancer with different PD-L1 tumor proportion scores", Lung Cancer, 136, pp. 98-101.

\title{
ĐÁNH GIÁ HIỆU QUẢ CỦA PHƯƠNG PHÁP CAN THIỆP NộI MẠCH TRONG ĐIỀU TRI CHẢY MÁU TÁ TRÀNG
}

\author{
Lê Thanh Dũng ${ }^{1}$, Trương Bích $A^{2}{ }^{2}$, Thân Văn $S^{1}$
}

\section{TÓM TẮT}

Mục tiêu: Đánh giá tính hiệu quả và an toàn của phương pháp can thiệp nút mạch cầm máu trong điều trị bênh nhân (BN) chảy máu tá tràng cấp tính. Đối tượng và phương pháp nghiên cứu: Nghiên cứu hồi cứu/tiến cứu mô tả từ 01/01/2020 đến 31/05/2021, 21 BN được chẩn đoán chảy máu tá tràng và can thiệp nội mạch cầm máu tại Bệnh viên Hữu nghị Việt Đức. Kết quả: Tỷ lệ thành công về kỹ thuật và lầm sàng lần lượt là $21 / 21(100 \%)$ và $14 / 21(66,7 \%)$ trường hợp. Tỷ lệ biến chứng sớm chảy máu tái phát chiếm 4/21(19\%), trong đó 1 BN được nút mach lần hai, 3 BN được nội soi nhắc lại hoặc phẫu thuật câm máu sau nút, 1 BN u tá tràng sau nút mach có biến chứng thiếu máu tá tràng được kiểm tra lại bằng nội soi và điều trị phẫu thuật. Tỷ lệ tử vong trong vòng 30 ngày sau nút là $9 / 21(42.8 \%)$, trong đó 2 BN nặng lên do u tiến triển mà không có biểu hiênn chảy máu tiêu hóa tái phát. Kết luận: Can thiệp nút mach cầm máu là một phương pháp an toàn, hiêuu quả trong kiểm soát chảy máu tá tràng thất bại với điêuu trị cầm máu

\footnotetext{
${ }^{1}$ Bệnh viện Hữu nghị Việt Đức

${ }^{2}$ Bệnh viện Đa khoa Hồng Ngọc

Chịu trách nhiệm chính: Lê Thanh Dũng

Email: Drdung74@gmail.com

Ngày nhân bài: 28.7.2021

Ngày phản biên khoa họ: 28.9.2021

Ngày duyệt bài: 4.10.2021
}

qua nội soi, nhất là đối với những BN thuộc nhóm cao tuổi, có bệnh lý nội khoa kết hợp.

\section{SUMMARY \\ THE RESULTS OF THE ENDOVASCULAR EMBOLIZAITON IN TREATMENT OF DUODENAL BLEEDING}

Purpose: To evaluate the efficacy and safety of endovascular embolization in treatment of acute duodenal bleeding. Materials and method: Retrospective and prospective descriptive study, from January 2020 to June 2021, 21 cases diagnosed as duodenal bleeding, were alternatively attempted to the transcatheter arterial embolization (TAE) under the guidance of DSA (digital subtraction angiography). Results: The technical and clinical success rates of TAE were respectively $21 / 21(100 \%)$ and $14 / 21$ $(66,7 \%)$. The early complication of recurrent bleeding rate for $4 / 21(19 \%)$, of which 1 patient was embolized for the second time, the last 3 cases were repeated endoscopic or hemostasis surgery secondary. There was 1 case with duodenal ischemic complication checked by repeated endoscopic post embolotherapy due to duodenal tumor, followed by surgical intervention. Mortality rate within 30 days after embolization was $9 / 21(42.8 \%), 2$ patients had poor prognosis due to tumor progression without rebleeding, the remaining patients was affected by underlying diseases, coagulation disorders, death leaded by hemorrhagic shock or multiple organ failure. 
Conclusion: The hemostatic embolization therapy in the treatment of duodenal bleeding has been shown to be a safe and effective method in the management and control of duodenal hemorrhage refractory to endoscopic treatment, especially for elderly patients with severe comorbidities and high risks.

Keywords: duodenal hemorrhage, duodenal ulcer, non-variceal upper gastrointestinal bleeding, transcatheter arterial embolization, hemostatic embolotherapy.

\section{I. ĐẶT VẤN ĐỀ}

Xuất huyết tiêu hóa cao có nguyên nhân từ loét dạ dày - tá tràng chiếm tỷ lệ xấp xỉ $60 \%$, trong đó chảy máu tá tràng do loét chiếm 17$37 \%$. Nội soi dạ dày tá tràng cầm máu vẫn là phương pháp điều trị chính với tỷ lệ thành công (80-90\%), nhưng tỉ iệ chảy máu tái phát vẫn ở khoảng $20 \%$ và tử vong vào khoảng $10 \%$, đặc biệt ở nhóm BN cao tuổi, nhiều bệnh kết hợp hoặc cần truyền máu với số lượng lớn ${ }^{1}$. Nhóm BN chảy máu nguy cơ cao sau khi đã áp dụng điều trị bảo tồn bằng nội khoa hoặc can thiệp nội soi cầm máu thất bại được xem xét điêu trị câm máu bằng phẫu thuật hoặc can thiệp nội mạch. Bên cạnh những tiến bộ và cải thiện thì can thiệp ngoại khoa vẫn có tỉ lệ gây tử vong cao từ 20$50 \%{ }^{2}$. Các báo cáo trong một thập kỷ qua cho thây những kết quả khả quan về tính hiệu quả và an toàn của phương pháp can thiệp nút mạch cầm máu trong chảy máu tá tràng với tỷ lệ thành công về kỹ thuật đạt 90 - 100\% và về mặt lâm sàng $60-94 \%$. Tỷ lệ tái chảy máu $8-55 \%$, tỷ lệ tử vong $4-33 \%{ }^{2}$.

Tại Việt Nam, hiện chưa có báo cáo nào về tính an toàn, hiệu quả của can thiệp nút mạch cầm máu tá tràng. Vì vậy, chúng tôi tiến hành nghiên cứu: "Đánh giá kết quả điều trị của phương pháp can thiệp nội mạch trong điều trị chảy máu tá tràng".

\section{II. ĐỐI TƯƠNGG VÀ PHƯƠNG PHÁP NGHIÊN CỨU}

Đối tượng nghiên cứu: $21 \mathrm{BN}(\mathrm{BN})$ chảy máu tá tràng được can thiệp nút mạch cầm máu tại Bệnh viện Việt Đức từ tháng 01 năm 2020 đến tháng 05 năm 2021.

Tiêu chuẩn lựa chọn: Tất cả BN được chẩn đoán chảy máu tá tràng bằng nội soi và/ hoặc bằng chụp cắt lớp vi tính (CLVT), được điều trị tích cực hồi sức bù tuần hoàn, điêu trị nội khoa bằng kháng sinh, ức chế bơm proton, được can thiệp nội soi cầm máu hoặc can thiệp phẫu thuật nhưng không hiệu quả và được chỉ định can thiệp nút mạch cầm máu. Các BN được giải thích về phương pháp điều trị và đồng ý tham gia nghiên cứu, có hồ sơ lưu trữ.
Phương pháp nghiên cứu: nghiên cứu hồi cứu/tiến cứu mô tả cắt ngang.

Quy trình chụp mạch và can thiệp nút mạch: Tất cả các trường hợp đều được chụp mạch số hóa xóa nền (DSA) đánh giá tổng thể động mạch thân tạng và mạc treo tràng trên, quy trình thực hiện với catheter $5 F$ (Yashiro, Terumo, Japan). Chụp siêu chọn lọc bằng microcatheter 1.8-2.7F (Progreat, Terumo, Japan) các nhánh mạch: động mạch gan riêng, động mạch vị tá tràng, động mạch tá tụy dưới hoặc các nhánh động mạch dựa vào vị trí xác định trên CLVT và/hoặc nội soi.

Khi thuốc cản quang hiện hình ổ giả phình hoặc ổ thoát thuốc hoặc ổ tăng sinh mạch quanh vùng tá tụy, thủ thuật nút mạch sẽ được thực hiện theo kỹ thuật Sandwich ( khi có vòng nối rộng rãi) hoặc nút siêu chọn lọc nhánh mạch tổn thương. Những trường hợp DSA không thấy tổn thương, can thiệp nút mạch dựa trên vị trí cặp clip đánh dấu khoanh vùng chảy máu của nội soi hoặc dựa vào vị trí chảy máu trên CLVT trước đó.

Đánh giá kết quả điêuu trị: Thành công về mặt kỹ thuật của phương pháp nút mạch được xác định khi tổn thương không còn ngấm thuốc trên hình ảnh chụp mạch kiểm tra sau nút mạch. Thành công của phương pháp về mặt lâm sàng được xác định khi không còn dấu hiệu chảy máu trong thời gian nằm viện và/hoặc không có tử vong liên quan đến chảy máu sau can thiệp nút mạch.

Phân tích số liệu: Hiêu quả điều trị dựa vào dấu hiệu tổn thương không còn ngấm thuốc khi chụp mạch kiểm tra sau nút và tính an toàn của phương pháp được đánh giá theo tỷ lệ biến chứng trong quá trình can thiệp nút mạch, biến chứng sớm bao gồm thiếu máu tá tràng, chảy máu tái phát. Tỷ lệ tái phát và tỷ lệ tử vong trong vòng 30 ngày cũng được thống kê. Tính toán và phân tích trên phần mềm SPSS 20.0.

\section{KẾT QUẢ NGHIÊN CỨU}

Trong số $21 \mathrm{BN}$ tham gia nghiên cứu có 16

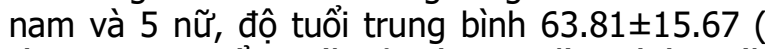
từ $28-93$ tuổi). Tất cả các $B N$ đều có ít nhất một bệnh lý nên kết hợp (bảng 1). Các nguyên nhân của chảy máu xác định qua nội soi và CLVT ổ bụng có tiêm thuốc cản quang: loét tá tràng (12/21), khối u xâm lấn gây chảy máu tá tràng (3/21), khối u xâm lấn kèm tổn thương loét tá tràng $(3 / 21)$, sau phẫu thuật loét dạ dày - tá tràng (3/21). Có 18/21 BN được can thiệp nội soi cầm máu nhưng không hiệu quả.

Bảng 1. Tiền sử bệnh của các bệnh nhân 


\section{trong nghiên cứu}

\begin{tabular}{|c|c|}
\hline Tîên sử bệnh & $\begin{array}{l}\text { Số lượng } \\
(\%) \text { BN }\end{array}$ \\
\hline Bệnh lý tim mạch & $5(23,8 \%)$ \\
\hline Bệnh lý gan mạn tính & $9(42,8 \%)$ \\
\hline Bệnh lý thận mạn tính & $5(23,8 \%)$ \\
\hline Bệnh lý cơ xương khớp & $4(19,0 \%)$ \\
\hline Khối u / ung thư' & $6(28,6 \%)$ \\
\hline $\begin{array}{l}\text { Bệnh lý toàn thân /nôi tiết (đái } \\
\text { tháo đường) }\end{array}$ & $8(38,0 \%)$ \\
\hline $\begin{array}{c}\text { Tiền sử phâu thuật trong vòng } \\
30 \text { ngày }\end{array}$ & $12(57,1 \%)$ \\
\hline Tiền sử loét dạ dày - tá tràng & $6(28,6 \%)$ \\
\hline
\end{tabular}

Có 20/21 trường hợp có chảy máu từ mức độ vừa (khi mạch $(\mathrm{M}) 100$ - 120 lần/phút, huyết áp $(\mathrm{HA}) 80-100 \mathrm{mmHg}$, hồng câuu $(\mathrm{HC}) 2.5-3 \mathrm{~T} / \mathrm{L}$, Hemoglobin (Hb) $90-100 \mathrm{~g} / \mathrm{L}$, Hematocrit (HCT) $30-35 \%$, có thể truyền $250-500 \mathrm{ml}$ máu) đến nặng $(M>120$ lân/phút, $\mathrm{HA}<80 \mathrm{mmHg}, \mathrm{HC}$ $<2.5 \mathrm{~T} / \mathrm{L}, \mathrm{Hb}<80 \mathrm{~g} / \mathrm{L}, \mathrm{HCT}<30 \%$, truyền ít nhất $1000 \mathrm{ml}$ máu) ${ }^{3}$. Chỉ số $\mathrm{Hb}$ trung bình trước nút mạch là $88.33 \pm 22.15 \mathrm{~g} / \mathrm{L} ; 12 / 21$ BN có mạch $\geq$ 100 lần/phút và $3 / 21$ có huyết áp tâm thu < $100 \mathrm{mmHg}$. Các $B N$ này được truyền từ $500 \mathrm{ml}$ đến $1400 \mathrm{ml}$ khối hồng cầu và từ $200 \mathrm{ml}$ đến $300 \mathrm{ml}$ huyết tương tươi đông lạnh trước khi can thiệp nội mạch. 4 BN có rối loạn đông máu (INR $>1,5$ và/hoặc tiểu cầu < $80 \mathrm{G} / \mathrm{L}$ hoặc thời gian hoạt hóa thromboplastin (APTT) kéo dài >45 giây).

Dâu hiệu tổn thương trên CLVT: 7/21 (33.3\%) trường hợp có ổ thoát thuốc, $5 / 21 \mathrm{BN}$ có ổ thoát thuốc (23.8\%), 6/21 ca có khối u tăng sinh mạch vùng tá tụy $(28.6 \%), 7 / 21$ ca có ổ máu tụ quanh tá tràng (33.3\%).

Chụp DSA phát hiện tổn thương ở 17/21 trường hợp (80.9\%): 7/21 BN có ổ thoát thuốc (33,3\%), tương tự với hình ảnh CLVT, 8/21 BN có ổ giả phình $(38,1 \%)$ (trên cắt lớp chỉ phát hiện được 5/21 trường hợp $(23,8 \%)), 2 / 21$ BN có hình ảnh tăng sinh mạch quanh khối u vùng tá tụy $(9,5 \%)$.

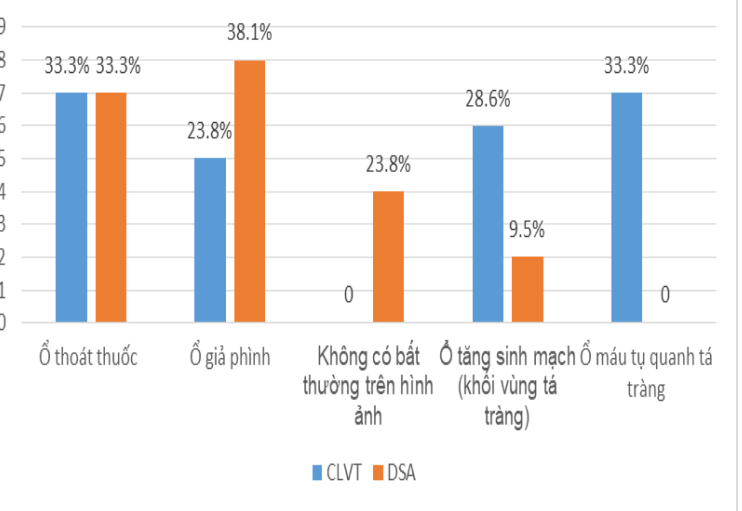

Biêu đồ 1: hình ảnh các tổn thương vùng tá tràng trên CLVT và DSA

Tổn thương xuất phát chủ yếu từ động mạch vị tá tràng chiếm $17 / 21(81 \%)$ bn, tiếp đến là động mạch tá tụy trên chiếm $6 / 21(28,6 \%)$, tá tụy dưới $6 / 21(28,6 \%)$, có $2 / 21$ ca tổn thương động mạch môn vị chiếm $(9,5 \%), 1 / 21$ ca tổn thương nhánh động mach tụy lưng $(4,8 \%)$.

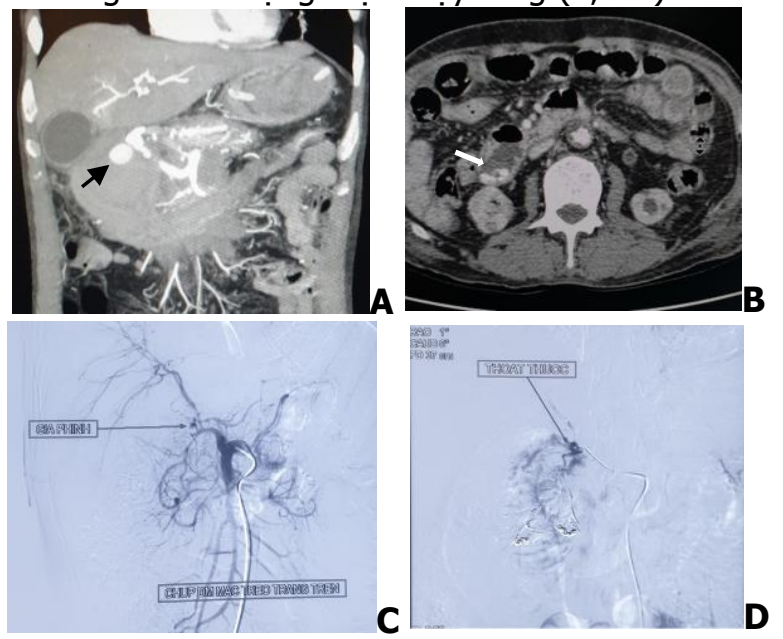

Hình 1. Minh hoạ hình ảnh chảy máu tá tràng trên CLVT và DSA

$A \& C$. Ổ giả phình ĐM vị tá tràng trên trên $C T A$ và $D S A$, xuất phát từ ĐM mạc treo tràng trên (mũi tên). B. Máu tụ trong lòng tá tràng (mũi tên trắng). D. Ổ thoát thuốc từ ĐM vị tá tràng.

Kết qủa nút mạch, tất cả các trường hợp (100\%) tổn thương không còn ngấm thuốc khi chụp mạch kiểm tra sau nút. 14/21 trường hợp được nút kết hợp giữa coils và hốn hợp keo sinh học Histoacryl và Lipiodol $(66.7 \%), 1 / 21$ ca bệnh nút kết hợp giữa keo sinh học và Spongel $(4.8 \%)$, $3 / 21$ trường hợp dùng coils (14.3\%) trong đó có 1 trường hợp nút đóng ổ giả phình kich thước lớn (đường kính 35mm, cổ hep), 3/21 (14.3\%) trường hợp còn lại nút bằng hồn hợp keo sinh học với tỷ lệ $1: 2 ; 1: 3$ và $1: 5$. Trong nghiên cứu này có 4/21 BN không thây ổ tổn thương trên chụp mạch (19\%), được nút mạch dựa trên kết quả của nội soi và CLVT: $3 \mathrm{BN}$ được nút kết hợp giữa coils và keo sinh học, trường hợp còn lại được nút kết hợp keo sinh học và Spongel.

Bảng 2. Sử dụng vật liệu nút mạch trong nghiên cứu

\begin{tabular}{|c|c|}
\hline Vật liệu nút mạch & $\begin{array}{c}\mathbf{N = 2 1} \\
(\mathbf{1 0 0} \%)\end{array}$ \\
\hline Coils & $3(14.3 \%)$ \\
\hline Coils + Keo sinh học Histoacryl & $14(66.7 \%)$ \\
\hline Keo Histoacryl + Spongel & $1(4,8 \%)$ \\
\hline Keo Histoacryl & $3(14.3 \%)$ \\
\hline
\end{tabular}


Hiệu quả điều trị sau nút mạch: không có trường hợp nào ghi nhận có biến chứng liên quan đên thủ thuật nút mạch cầm máu, $4 / 21$ trường hợp chảy máu tiếp diễn sau nút mạch (19\%): một trường hợp được nút tiếp lần hai, lâm sàng dần ổn định và không có tái phát sau can thiệp lần hai. Một trường hợp được nội soi cầm máu lại sau nút mạch. Hai trường hợp còn lại được phẫu thuật cấp cứu cầm máu sau nút mạch và không còn chảy máu tái phát sau đó.

Có 9/21 (42.8\%) trường hợp tử vong trong vòng 30 ngày sau nút trong đó: $7 / 21$ (33.3\%) trường hợp tử vong thuộc nhóm tuổi cao (từ 56 đến 93 tuổi) có từ hai bệnh lý nền kết hợp, biểu hiện rối loạn đông máu và tiếp tục chảy máu sau điều trị. Hai trường hợp tử vong không liên quan đến chảy máu tái phát.

\section{BÀN LUẬN}

Phần lớn xuất huyết tiêu hóa trên đáp ứng đối với can thiệp nội soi cầm máu. Khi nội soi cầm máu thất bại, phẫu thuật cầm máu có tỷ lệ tái phát cao, chiếm khoảng $75 \%$, với tỷ lệ tử vong khoảng $20-50 \%{ }^{1}$.

Trong nghiên cứu này, tuổi trung bình là

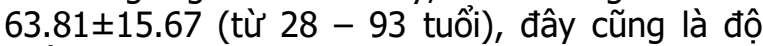
tuổi gặp trong các nghiên cứu khác ${ }^{4}$. Có 21 BN 16 nam $(76.2 \%)$ và $5 \mathrm{BN}$ nữ chiếm $23.8 \%$, có sự tương đồng ở những báo cáo khác về sự ghi nhận chảy máu tá tràng thường gặp ở nam giới ${ }^{4}$.

Một trong những đặc điểm của xuất huyết tiêu hoá chính là tính chảy máu ngắt quãng, do đó các phương tiện chẩn đoán hình ảnh chỉ có thể chẩn đoán được khi bắt đúng thời điểm chảy máu. Vì vậy, các dấu hiệu về vị trí ổ loét hay máu cục bám thành tá tràng trên nội soi là những dấu mốc rất quan trọng giúp định hướng cho can thiệp nội mạch. Trong nghiên cứu của chúng tôi DSA phát hiện ra tổn thương trong $81 \%$ các trường hợp: ổ thoát thuốc ở $1 / 3$ các trường hợp; ổ giả phình chiếm $38.1 \%$. Nhóm tác giả Saad N.E.A (2005) và Madhusudhan KS $(2016)^{5}$ chỉ ra CLVT đa dãy chụp mạch máu là phương pháp không xâm lấn có độ nhạy cao nhất phát hiện ổ giả phình. Trong nghiền cứu này, DSA có tỷ lệ phát hiện ra ổ giả phình cao hơn CLVT, sự khác biệt này có thể do số lượng BN chưa nhiều và một số BN không chụp CLVT trước nút mạch (9.5\%).

Về động mạch cấp máu, theo kết quả nghiên cứu của chúng tôi, đa số các tổn thương mạch liên quan đến động mạch vị tá tràng, chiếm $81 \%$. Đây là vị trí giàu mạch nuôi cùng với rất nhiều tuần hoàn bàng hệ, do đó nguy cơ thiếu máu sau can thiệp thấp, nhưng nguy cơ tái phát thường cao. Do đó, kiểm soát hết tất cả các nguồn mạch nuôi là rất quan trọng để có thể đạt được hiêu quả tối đa.

Thành công về mặt kỹ thuật trong nghiên cứu của chúng tôi đạt được ở tất cả các BN, kết quả này tương đồng với các kết quả từ các nghiên cứu trước đây². Về mặt lâm sàng, trong nghiên cứu của chúng tôi, mặc dù tỷ lệ tử vong chung là $42,8 \%(9.5 \%$ BN tử vong do tiến triển của khối u), nhưng chỉ $19 \%$ tổng số BN có chảy máu tái phát trong vòng 30 ngày. Kết quả này cũng tương đồng với nghiên cứu của nhóm tác giả khác Encarnaction hay nhóm tác giả De Wispelaere với tỷ lệ tử vong khoảng 40-45\% ${ }^{6}$. các BN cao tuổi, có nhiều bệnh lý nền, cùng với những rối loạn huyết động nặng trước khi can thiệp có lẽ là những lý do giúp giải thích nguy cơ tử vong cao dù tỷ lệ chảy máu tái phát và biến chứng thấp.

Phần lớn các trường hợp chúng tôi nút coils chặn đầu xa rồi nút tắc thân động mạch và đoạn gần bằng hỗn hợp Histoacryl và Lipiodol, tỷ lệ $1: 2,1: 3(66.7 \%) .14 .3 \%$ trường hợp được dùng coils đơn lẻ nút tắc đoạn động mạch vị tá tràng lần lượt có ổ giả phình/ổ thoát thuốc và $4.8 \%$ trường hợp nút đóng ổ giả phình kích thước lớn, cổ hẹp. Có $14.3 \%$ các trường hợp được nút siêu chọn lọc gây tắc hoàn toàn bằng keo sinh học vì trong đó có 2 ca tổn thương chảy máu từ động mạch môn vị cấp máu vùng hành tá tràng. Việc lựa chọn vật liệu nút mạch vẫn là vấn đề tranh cãi, phụ thuộc vào kinh nghiệm của người thực hiện. Các nghiên cứu trước đây có những kết quả độ biến thiên lớn $9-47 \% \%^{2}$. Sử dụng coils đơn thuần có tỷ lệ chảy máu tái phát cao hơn, ngược lại sử dụng NBCA đơn thuần cho khả năng nút mạch triệt để hơn nhưng cũng kèm theo nguy cơ cao hơn về thiếu máu hoặc hẹp tá tràng ${ }^{7}$. Ở nghiên cứu này, chúng tôi ghi nhận tỷ lệ tái chảy máu trong $19 \%$ ca bệnh không phụ thuộc vào chọn lựa vật liệu nút mạch, một nửa số ca nhóm này tử vong được nút kết hợp giữa coils và keo sinh hoc, khả năng cao do hê quả của các rối loạn mất bù trên nền nhiều bệnh lý kết hợp, một nửa còn lại ca loét - chảy máu tá tràng có tiền sử phẫu thuật lớn như cắt túi mật hoại tử hoặc thay khớp háng, kèm với số lượng máu truyền máu lớn, được coi là những nguy cơ phổ biến gây chảy máu tái phát. Nhiều tác giả có sự tương đồng về quan điểm cho rằng $90 \%$ các trường hợp chảy máu tá phát xảy ra trong vòng 7 ngày sau can thiệp ${ }^{8}$. Dù vậy $1 / 4$ bênh nhân trong nhóm này dấu hiệu chảy máu lại xảy ra ở ngày thứ 29, 30 sau nút mạch và được nút mạch 
thành công lần hai.

1 trường hợp ghi nhận có biểu hiện thiếu máu hoại tử ổ loét cạnh khổi u vùng tá tràng khi nội soi sau nút mach, sau đó đã được loại bỏ khối u kèm ổ tổn thương vùng tá tràng bằng phẫu thuật. Bệnh nhân được nút chặn các nhánh trong vòng nối tá tụy và động mạch vị tá tràng bằng coils và nút tắc bằng keo sinh học NBCA. Tỷ lệ gây thiếu máu ruột sau nút động mạch vùng tá tụy là thấp do sự phong phú của hệ thống tưới máu khu vực này. Trường hợp này có thể giải thích do ổ loét lớn chiếm $1 / 2$ chu vi lòng tá tràng, sau nút rộng tãi động mạch vị tá tràng và vòng nối tá tụy nên có dấu hiệu thiếu máu hoại tử.

Nghiên cứu này vẫn còn nhiều hạn chế. Trước hết, số lượng $\mathrm{BN}$ trong nghiên cứu còn nhỏ, chưa mang tính đại diện cho quần thể, các số liệu còn đơn giản, mang tính mô tả. Hơn nữa, nghiên cứu này có thời gian theo dõi ngắn và mới chỉ đề cập tới các biến chứng cấp tính mà chưa đánh giá được các biến chứng và di chứng xa sau điều trị. Những nghiên cứu với số lượng cõ̃ mẫu lớn hơn, thời gian theo dõi dài hơn, so sánh ngẫu nhiên có đối chứng cần được thực hiện để đánh giá chi tiết hơn về tính an toàn, hiệu quả của phương pháp này.

\section{KẾT LUÂN}

Kết quả nghiên cứu cho thấy can thiệp nút mạch là phương pháp hiệu quả và an toàn có thể thực hiện cho những trường hợp chảy máu tá tràng đã̉ thất bại với điều trị nội khoa và nội soi cầm máu.

\section{TÀI LIÊU THAM KHẢO}

1. Mille $M$, Engelhardt $T$, Stier A. Bleeding Duodenal Ulcer: Strategies in High-Risk Ulcers. Visc Med. 2021;37(1):52-62. doi:10.1159/000513689

2. Loffroy $R$, Favelier $S$, Pottecher $P$, et al. Transcatheter arterial embolization for acute nonvariceal upper gastrointestinal bleeding: Indications, techniques and outcomes. Diagnostic and Interventional Imaging. 2015;96(7-8):731744. doi:10.1016/j.diii.2015.05.002

3. Hà Văn Quyết. Chảy máu đường tiêu hóa. In: Bệnh Học Ngoại Dùng Cho Sau Đại Học Tập I. Nhà xuất bản y hoc; 2006:36-37.

4. Loffroy $\mathbf{R}$, Guiu B, $\mathbf{D}^{\prime}$ Athis $\mathbf{P}$, et al. Arterial Embolotherapy for Endoscopically Unmanageable Acute Gastroduodenal Hemorrhage: Predictors of Early Rebleeding. Clinical Gastroenterology and Hepatology. doi:10.1016/j.cgh.2009.02.003

5. Madhusudhan KS, Venkatesh HA, Gamanagatti S, Garg P, Srivastava DN. Interventional Radiology in the Management of Visceral Artery Pseudoaneurysms: A Review of Techniques and Embolic Materials. Korean J Radiol. 2016;17(3):351-363. doi: $10.3348 /$ kjr.2016.17.3.351

6. De Wispelaere JF, De Ronde T, Trigaux JP, de Cannière L, De Geeter $\mathbf{T}$. Duodenal ulcer hemorrhage treated by embolization: results in 28 patients. Acta Gastroenterol Belg. 2002;65(1):6-11.

7. Kuyumcu G, Latich I, Hardman R, Fine G, Oklu R, Quencer K. Gastrodoudenal Embolization: Indications, Technical Pearls, and Outcomes. JCM. 2018;7(5):101. doi:10.3390/jcm7050101

8. Zhou T-Y, Sun J-H, Zhang Y-L, et al. Postpancreaticoduodenectomy hemorrhage: DSA diagnosis and endovascular treatment. Oncotarget. 2017;8(43):73684-73692.

doi:10.18632/oncotarget. 17450

\section{ĐÁNH GIÁ TÍNH ĐÔNG NHẤT VÀ Đô ỔN ĐINH MẪU HBV DNA ĐÔNG KHÔ THEO TIÊU CHUẨN VỀ MẪU NGOẠI KIỂM}

\section{TÓM TẮT}

Mục tiêu: Xây dựng quy trình sản xuất mẫu HBV DNA đông khô sử dựng trong ngoại kiểm. Đánh giá tính đồng nhất và độ ổn định của mẫu huyết tương HBV DNA đông khô sau sản xuất. Phương pháp

\footnotetext{
${ }^{1}$ Đai hoc Y Dướ TP.HCM

2Bềnh viên Đai hoc Y Dước TP.HCM

${ }^{3}$ Trung tâm Kiểm chuân chất lượng Y học - Đại học Y Dướ TP.HCM

Chịu trách nhiệm chính: Vũ Quang Huy

Email: drvuquanghuy@gmail.com

Ngày nhận bài: 29.7.2021

Ngày phản biên khoa hoc: 27.9.2021

Ngày duyệt bài: 1.10.2021
}

\section{Vũ Quang Huy ${ }^{1,2,3}$, Trần Thị Mỹ Qui ${ }^{1}$}

nghiên cứu: Nghiên cứu thực nghiêm trên các mẫu huyết tương dương tính HBV DNA, đánh giá tính đồng nhất và độ ổn định của mẫu huyết tương HBV DNA đông khô bằng kiểm đinh so sánh môt trung bình (Oneway ANOVA) và phép kiểm T- test. Kết quả: Mẫu huyết tương HBV DNA đông khô với 3 mức nồng độ đạt tính đồng nhất, độ ổn định vận chuyển trong 7 ngày. Mẫu đat độ ổn đỉnh bảo quản tai nhiệt đô $-20^{\circ} \mathrm{C}$ lên đến 150 ngày, ở nhiệt độ $2-8^{\circ} \mathrm{C}$ trong 90 ngày, ở nhiệt độ $25^{\circ} \mathrm{C}$ và $37^{\circ} \mathrm{C}$ trong 10 ngày (giá trị $p>$ 0.05). Kết luận: Quy trình sản xuất mẫu HBV DNA đông khô đã được xây dựng thành công. Tính đồng nhất và độ ổn định của các mẫu được sản xuất đáp ứng các tiêu chí của tiêu chuẩn ISO 13528:2015 và ISO guide 35. Tư khóa: Đánh giá, HBV DNA, huyết tương đông khô. 